\title{
Systemic administration of a broadly-neutralizing IgG antibody to generate HIV-neutralization responses in breast milk
}

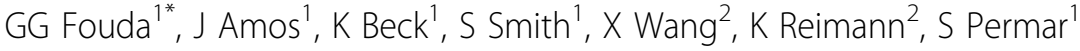 \\ From AIDS Vaccine 2012 \\ Boston, MA, USA. 9-12 September 2012
}

\section{Background}

Postnatal acquisition of HIV during breastfeeding is responsible for almost half of 350,000 pediatric HIV infections occurring yearly. Thus, there is an urgent need to develop immunologic interventions to impede breast milk transmission of HIV, including immunization and passive infusion strategies. We previously observed that functional antibody responses in milk of HIV- infected mothers mirror that in plasma, suggesting that inducing strong systemic IgG responses may lead to virus inhibition in milk. Therefore, we investigated the kinetics of binding and neutralizing antibodies in plasma and milk of passively- infused lactating rhesus monkeys.

\section{Methods}

The broadly neutralizing antibody b12 engineered in a rhesus IgG1 backbone was administered intravenously to four hormone-induced, lactating female rhesus monkeys at a dose of $5 \mathrm{mg} / \mathrm{kg}$. Milk and blood was collected frequently until $72 \mathrm{~h}$ post infusion, then weekly for 4 weeks. Levels of the infused antibody and the neutralizing activity in the milk and systemic compartments were measured at each time-point.

\section{Results}

The b12 IgG levels peaked 1 hour post-infusion in plasma and 24 to $72 \mathrm{~h}$ post-infusion in milk. The median peak b12 antibody levels were $87,503 \mathrm{ng} / \mathrm{ml}$ (range 62,548 to $101,525 \mathrm{ng} / \mathrm{ml}$ ) in plasma and $47 \mathrm{ng} / \mathrm{ml}$ (range 16 to $202 \mathrm{ng} / \mathrm{ml}$ ) in milk. The peak in plasma neutralization was 1 to 6 hours post-infusion and the neutralization titer slowly declined after 24 hours. The peak neutralization titer in milk (median ID50: 70, range: 50-103) was approximately two logs lower than in plasma (median ID50: 2313, range: 1875-3128) and occurred within 24 hours post-infusion in 3 of 4 animals. There was a significant correlation between neutralization titers in milk and plasma $(\mathrm{r}=0.48, \mathrm{p}=0.01)$.

\section{Conclusion}

The neutralizing activity detected in milk following systemic administration of a broadly- neutralizing IgG antibody supports the induction of strong systemic antiHIV IgG responses to generate HIV inhibitory antibodies in breast milk.

\section{Author details}

${ }^{1}$ Duke Human Vaccine Institute, Durham, NC, USA. ${ }^{2}$ Beth Israel Deaconess Medical Center, Boston, MA, USA.

Published: 13 September 2012

doi:10.1186/1742-4690-9-S2-P196

Cite this article as: Fouda et al:: Systemic administration of a broadlyneutralizing IgG antibody to generate HIV-neutralization responses in breast milk. Retrovirology 2012 9(Suppl 2):P196.

${ }^{1}$ Duke Human Vaccine Institute, Durham, NC, USA

Full list of author information is available at the end of the article

(c) 2012 Fouda et al; licensee BioMed Central Ltd. This is an Open Access article distributed under the terms of the Creative Commons Attribution License (http://creativecommons.org/licenses/by/2.0), which permits unrestricted use, distribution, and reproduction in any medium, provided the original work is properly cited. 